\title{
Libellulidae (Insecta: Odonata) from Itapiracó reserve, Maranhão, Brazil: new records and species distribution information
}

\author{
Paulo De MARCO JÚNIOR ${ }^{1}$
}

\section{ABSTRACT}

In this work, I apply a simple protocol to species occurrence inventory of Odonata in a region of Maranhão state which has very few distributional records. Some relations between species occurrence and environmental characteristics are discussed, mainly in relation to the high occurrence of Erythemis. Eighteen new records are presented discussing the role of this approach to generate useful information for conservation purposes.

KEYWORDS: Rapid Assessment protocol, Biodiversity, Odonata, Environmental Impact, Conservation.

\section{Libellulidae (Insecta: Odonata) da Reserva Itapiracó, Maranhão, Brasil: novos registros e informações sobre distribuição de espécies}

\section{RESUMO}

Nesse trabalho eu aplico um protocolo simples para o levantamento da ocorrência de espécies de Libellulidae em uma região no estado do Maranhão, que possui pouquíssimas informações. Algumas relaçôes entre ocorrências de certas espécies e características do ambiente além de padrões de co-ocorrência são discutidas, principalmente em relação à elevada ocorrência do gênero Erythemis. Dezoito ocorrências novas são listadas e é discutido o papel desse tipo de abordagem para gerar informações de interesse para conservação de espécies.

PALAVRAS-CHAVE: Levantamento rápido de espécies, Biodiversidade, Odonata, impacto ambiental, Conservação. 
In this paper I present the results of a survey in an area at Itapiracó, Maranhão, Brazil, that was a reserve invaded by homeless people. This survey was made mainly to=acquire biogeographic data in an area with very few studies in Odonata and with great possible relevance to conservation. In a recent revision, De Marco \& Vianna (2005) showed that the state of Maranhão has very scarce distributional information about its odonate fauna. However, a very rich fauna is expected in this region due to its biogeographical affinity both to Brazilian northeastern fauna in arid climates as well as to its Amazonian components.

The Itapiracó state reserve area (-2.524218 S,-44.206094 W, location in decimal degree format) is located on the São Luís island with a tropical warm semi-humic climate $=$ and an annual precipitation close to $1800 \mathrm{~mm}$ (Nimer, 1989). The vegetation of the area-includes a variety of palm tree formations mainly dominated by burity (Mauritia vinifera) and juçara (Euterpe oleraceae) near rivers, bordered by cerrado and restinga systems (Rebêlo \& Silva, 1999).

Four main systems were observed at Itapiracó which helps understand the alterations of the odonate community: natural regeneration areas, temporary pools, lakes/impoundments, and streams. Regeneration areas (RA) surrounded almost all the forested areas of the reserve and are characterized by the presence of Vismia spp. In most of the area, the Vismia individuals do not surpass $1-1.5 \mathrm{~m}$ in height, but it is difficult to=establish whether this is a result of a recent regeneration event or the poor condition of the sand soil. Temporary pools (TP) should be easy to find in the entire area in August, soon after the dry season ("Estiagem") begins. This area had intense direct human use and the passage of people and coachbuses which usually leave deep furrows in the soil, that appear to increase with heavy rains and become pools for a relative long time. I observed many-temporary pools in the regeneration areas. A dammed stream (DAM), nearly $10 \times 15 \mathrm{~m}$, is one of most important habitats for the odonate there, at least based on their abundance. This small impoundment was densely occupied by Nymphea aff. ampla and was surrounded by gramineae on one side and by secondary vegetation on the other. Besides this dam, I once visited a lake (L) with little aquatic vegetation surrounded by grass. Streams with wetlands (WET) are normally densely occupied by Jussara (Euterpe oleraceae), Babaçú (Orbygnia spp) e Carnaúba (Copernicia prunifera) in the region. These areas are usually shaded and bordered by complex vegetation. Macrophytes may be present, but in general they are of minor importance compared to grass. The streams studied were one shaded by forest (SF) and another used by the local community as a swimming pool (SS).

For two days in August 2000, I made an Odonata inventory at those areas described above from 10:00 to
12:00 hr. This inventory was made with the aid of 12 local community members with capture effort limited to the use of one insect-net (i.e.only one collector in the field at a time), totalling 4 collector-hours. Time was divided among habitats in direct relation to the abundance of new records. When no new species was observed at a site we would move to another place. Some species were not captured but=were recorded only if the identification was unequivocal (e.g. Brachymesia herbida Gundlach, 1889). In these cases it was marked as an observation in the result section.

The identification of species was made by comparing them with specimens in the collection deposited at the Laboratorio de Ecologia Teórica e Síntese (LETS/UFG) and with the use of keys at the generic level and descriptions (Montgomery, 1940; Borror, 1942; Borror, 1945; Garrison, 1990; Carvalho \& Calil, 2000; Costa et al., 2002). All Odonata scientific names used are based on the synonymic list of Garrison (1991).

The observations and captures were made with emphasis on Libellulidae, as many of the other families can pass easily unnoticed in the vegetation (e.g. Coenagrionidae) or $=$ may not have been active from 10:00 to 12:00 hr (e.g. some Aeshnidae and Gomphidae). Although other species are cited here, this methodology is primary efficient for the analysis of patterns in the community of Libellulidae present:

Brachmesia herbida: A single immature individual observed at RA and a mature observed at DAM.

Diastatops obscura (Fabricius, 1775): Occurred in DAM and WET.

Erythemis plebeja (Burmeister, 1839): common in DAM not observed in other sites; many males defending territories.

Erythemis carmelita (Williamson, 1923): commom in DAM, observed mainly perched in the higher vegetation $2-5 \mathrm{~m}$ above the water. At least two individuals observed with this behaviour.

Erythemis peruviana (Rambur, 1842): commom in DAM, some males defending territories.

Erythemis vesiculosa (Fabricius, 1775): Common in RA, feeding or pattrolling very near the soil over the vegetation (maximum $1 \mathrm{~m}$ above soil).

Erythrodiplax basalis (Kirby, 1897): Very frequent in WET, rare in DAM and SW. Many males were observed perched on vegetation and few possible females observed in the RA.

Erythrodiplax fusca (Rambur, 1842): single individual captured at DAM.

Erythrodiplax media Borror, 1942: several individuals defending territories in DAM and L.

Erythrodiplax paraguayensis (Förster, 1905): observed perched at lake margin $(\mathrm{L})$ and DAM. 
Miathyria marcella (Selys in Sagra 1857): Many small aggregation of 10 to 20 individuals observed at RA.

Micrathyria ocellata dentiens Calvert, 1909: Defending territory in DAM.

Micrathyria pseudeximia Westfall, 1992: defending territory in DAM and L.

Nephepeltia phryne (Perty, 1834): a single individual was captured inside the Forest near a trail. Apparent a near-mature male foraging.

Orthemia ambinigra Calvert, 1909: Frequent in TP and WET. Rarer than $O$. discolor in RA and DAM.

Orthemis discolor (Burmeister, 1839): Often observed at trails and RA, TP. In WET it was observed defending territory. Also observed near DAM and L. This species was frequntly observed defending territory agains $O$. ambinigra.

Perithemis lais (Perty, 1834): Frequent in DAM and L. Male defending territory and many copulation events observed.

Zenithoptera anceps Pujol-Luz, 1993: Commom in WET but also occurred at DAM.

Species of Zygoptera, not properly sampled by my sampling methods were:

Neoneura (Protoneuridae): Found perched in lower stems at the margin of SF. Very common.

Hetaerina sanguinea Selys, 1853 (Calopterygidae): Found in higher stems of grass at SW.

Ischnura fluviatilis Selys, 1876 (Coenagrionidae): Found in L, DAM and rare at WET.

An analysis of conservation value is mostly based on distributional records of faunal elements, with well determined geogaphic locations (Humphries et al., 1995; Winston \& Angermeier, 1995). However, De Marco \& Vianna (2005) observed that there are many distributional records with information as imprecise as "Brazil", or "Maranhão" or "Amazon". These broad geographical units do not properly describe the distribution for a conservation biogeography approach, however, it provides some information that could be useful in some other analysis. Here I apply the restrictive criteria which considers only distributional records by which we could determine the geographical (latitude/longitude) position directly from the bibliographic or collection information, or indirectly by georeferencing the information about collection locality. This is the same criteria used on a recent literature compilation of odonate distribution by De Marco \& Vianna (2005) which=recorded the presence of eight species in Maranhão (Table 1). We increased this list in 17 species, with samples from just one locality. This is an important picture of the present knowledge of Brazilian biodiversity and the obvious need for biodiversity inventories with focus on "white-spots" (areas with low amount of information on biodiversity).

The first aspect of this assemblage of odonate species that must be noted is the richness of Erythemis species. From the total of eigth species registered in Brazil (De Marco \& Vianna, 2005) four were observed in a single lentic water body. This poses an interesting question about the possible coexistence of those species in respect to the current niche theory (Vandermeer, 1972; Alley, 1982). One possibility is that these species present a resource partition on ecological space that can allow its coexistence. They are similar in size; and general behavioural observations of E. plebeja (De Marco et al., 2002) or E. peruvianna (De Marco et al., 2005) do not suggest any clear distinction of areas for male territorial defence. Another possibility, perhaps more reasonable, is that this is an non-equilibrium system strongly affect by dispersal-colonization effects. All these species had larger biogeographical distributions and appear to have high dispersal capabilities. A more detailed study is necessary to reveal whether those species have persistent populations here or are affected by some process similar to the ecological drift conceptualized by Hubbell (2001).

In some other libellulid genera, it is common to find co-occurring species as Erythrodiplax and Micrathyria (De Marco \& Latini, 1998; Ferreira-Peruquetti \& De Marco, 2002; De Marco et al., 2005). These genera are important

Table 1 - Records of Odonata species in Maranhão state that present geographic position information based on a literature review of 217 published articles.

\begin{tabular}{lllll}
\hline Species & Municipality & Latitude & Longitude & Literature reference \\
\hline Diastatops obscura & São Luis do Maranhão & $-2,583$ & $-44,283$ & Montgomery (1940) \\
Micrathyria ocellata & Gonçalves Dias & $-3,667$ & $-45,783$ & Santos (1949) \\
Micrathyria pseudeximia & Timon & $-5,094$ & $-42,836$ & Costa et al. (2002) \\
Uracis fastigiata & Rosário & $-2,934$ & $-44,235$ & Costa \& Santos (1997) \\
Uracis imbuta & Imperatriz & $-5,516$ & $-47,45$ & Costa \& Santos (1997) \\
Uracis imbuta & Rosário & $-2,934$ & $-44,235$ & Costa \& Santos (1997) \\
Uracis siemensii & Santa Luzia & $-2,583$ & $-44,283$ & Costa \& Santos (1997) \\
Zenithoptera anceps & Santa Luzia & $-2,583$ & $-44,283$ & Pujol-Luz \& Fonseca (1997) \\
Zenithoptera anceps & Imperatriz & $-5,516$ & $-47,450$ & Pujol-Luz \& Fonseca (1997) \\
Zenithoptera lanei & São Luís do Maranhão & $-2,583$ & $-44,283$ & Pujol-Luz \& Fonseca (1997) \\
\hline
\end{tabular}


components of tropical lentic waters but some of its species are also observed in lentic portions of streams (E. fusca and E. media).

The Libellulidae assemblage present here is also characterized by species with large biogeographic distribution (the Erythemis species, E. media, E. fusca. M. marcella, B. herbida, P. lais, D. obscura, $O$. discolor), a bionomic trait which is possibly associated-with the ability to sucessfully colonize in disturbed open habitats (De Marco, 1998) similar to the Itapiracó mosaic system. However, some remarkable absences are noted: Pantala flavescens (Fabricius, 1798) and Erythrodiplax umbrata (Linnaeus, 1758) which are present in almost every site with temporary ponds in Brazil. This is possibly a sampling error due to random factors or because individuals of this species may still be in the larval stage during sampling. Even assuming these possible underestimatives of odonate species composition, the use of a simple methodology as presented in this paper may help accelerate the accumulation of biogeographical information in Brazil. This effort should be directed towards areas about which biodiversity inventories are nearly absent, as shown=by De Marco \& Vianna (2005), and is the case of most of Maranhão.

\section{ACKNOWLEDGEMENT}

We especially would like to thank Murilo Drummond, Luis Fernando Gomes and the twelve teenagers who helped in the field work, and Flávia P. Lima who helped on a first draft of this paper.

\section{LITERATURE CITED}

Alley T.R. 1982 Competition theory, evolution, and the concept of an ecological niche. Acta Biotheoretica, 31: 165-179.

Borror D.J. 1942 A revision of the libelluline genus Erythrodiplax (Odonata). Columbus, Ohio

Borror D.J. 1945 A key to the New World genera of Libellulidae (Odonata). Annals of Entomological Society of America, 38: 168-194.

Carvalho A.L.; Calil E.R. 2000 Chaves de identificação para as famílias de Odonata (Insecta) ocorrentes no Brasil, Adultos e larvas. Papeis Avulsos de Zoologia, São Paulo, 41(15): 223-241.

Costa J.M.; Lourenço A.N.; Vieira L.P. 2002 Micrathyria pseudhypodidyma sp. n. (Odonata: LIbellulidae), com chave das espécies do gênero que ocorrêm no Rio de Janeiro. Neotropical Entomology, 31(3): 377-389.

Costa J.M.; Santos T.C. 1997 Intra- and interspecific variation in the genus Uracis Rambur, 1842, with a key to the known species (Anisoptera: Libellulidae). Odonatologica, 26(1): 1-7.

De Marco P.Jr. 1998 The Amazonian Campina dragonfly assemblage: patterns in microhabitat use and behavior in a foraging habitat. Odonatologica, 27(2): 239-248.
De Marco P.Jr.; Latini A.O. 1998 Estrutura de Guildas e Riqueza em Espécies em uma Comunidade de Larvas de Anisoptera (Odonata). In: Nessimian JL, Carvalho AL (eds) Oecologia Brasiliensis, vol. V. PPGE-UFRJ, p. 101-112.

De Marco P.Jr.; Latini A.O.; Resende D.C. 2005 Thermoregulatory constraints on behavior: patterns in a Neotropical dragonfly assemblage. Neotropical Entomology, 34(2): 155-162.

De Marco P.Jr.; Latini A.O.; Ribeiro P.H.E. 2002 Behavioural ecology of Erythemis plebeja (Burmeister) at a small pond in Southeastern Brazil (Anisoptera: Libellulidae). Odonatologica, 31(3): 305-312.

De Marco P.Jr.; Vianna D.M. 2005 Distribuição do esforço de coleta de Odonata no Brasil: subsídios para escolha de áreas prioritárias para levantamentos faunísticos. Lundiana, 6(supplement): 13-26.

Ferreira-Peruquetti P.; De Marco P.Jr. 2002 Efeito da alteração ambiental sobre comunidades de Odonata em riachos de Mata Atlântica de Minas Gerais, Brasil. Revista Brasileira de Zoologia, 19(2): 317-327.

Garrison R.W. 1990 A synopsis of the genus Hetaerina with descriptions of four new species (Odonata: Calopterigidae). Transactions of American Entomological Society, 116: 175-259.

Garrison R.W. 1991 A synonymic list of the new world odonata. Argia, 3(2): 1-30.

Hubbell S.P. 2001 The unified neutral theory of Biodiversity and Biogeography. Princeton University Press, Princeton and Oxford. 375p.

Humphries C.J.; Williams P.H.; Vanewright R.I. Measuring biodiversity value for conservation. 1995.

Montgomery B.E. 1940 A revision of the genus Diastatops (Libellulidae, Odonata) and a study of the leg characters of related genera. Lloydia, 3(4): 213-280.

Nimer E. 1989 Climatologia do Brasil. IBGE, Rio de Janeiro

Pujol-Luz J.R.; Fonseca R.R. 1997 Variação de coloração das asas e distribuição geográfica do gênero Zenithoptera Bates in Selys (Odonata, Libellulidae). Revista da Universidade Rural, Série Ciências da Vida, 19(1-2): 13-26.

Rebêlo J.M.M.; Silva F.S. 1999 Distribuição de abelhas Euglossini (Hymenoptera: Apidae) no estado do Maranhão, Brasil. Anais da Sociedade Entomologica do Brasil, 28(3): 389-401.

Santos N.D. 1949 Contribuição ao conhecimento da fauna de Pirassununga 6. Descrição da fêmea de Micrathyria catenata Calvert, 1909 e notas sobre M. ocellata dentiens Calvert, 1909 (Odonata, Libellulidae). Revista de Entomologia, Rio de Janeiro, 20: 159-164.

Vandermeer J.H. 1972 Niche theory. Annual Review of Ecology and Systematics, 3: 107-132.

Winston M.R.; Angermeier P.L. 1995 Assessing conservation value using centers of population density. Conservation Biology, 9(6): 1518-1527.

Recebido em 29/11/2006

Aceito em 16/09/2008 